за счет четких критериев, определяющих проектную деятельность, т.е. не все виды работ должны управляться проектными принципами. Так же за счет соответствия между типами проектов компании и ее организационной структурой, которая может не позволить организовать эффективное управление проектами.Результаты внедрения КСУП на предприятиях различных отраслей экономики дают положительные результаты по ключевым показателям: многократный рост эффективности управления проектами, снижение отклонений по срокам проектов, существенные снижения отклонений по бюджетам проектов, сокращение затрат руководителей проектов на контроль сроков проектов, сбор информации и контроль подрядчиков. Внедрение КСУП позволяет получать сводную информацию по проектам в режиме онлайн. КСУП позволяет работать компаниям как единый, слаженный механизм, позволяет повышать конкурентные позиции на рынке и добиваться успехов в бизнесе.

$$
* * *
$$

4. Управление проектами : учеб.пособие для студентов, обучающихся по специальности «Менеджмент организации» / И.И. Мазур[и др.]; под общ. Ред. И.И. Мазура и В.Д. Шапиро. - 6-е изд., стер. - М. : Издательство «Омега - Л», 2010. - 960 с.

\title{
Кичигина О.Ю. \\ Риск-ориентированный принцип управления при реализации образовательной услуги в высшей школе
} ФКОУ ВО «Кузбасский институт ФСИН России» (Россия, Новокузнеик)

doi:10.18411/spc-8-12-2017-25

idsp: 000001:spc-8-12-2017-25

В современных условиях качество подготовки специалистов - приоритетное направление деятельности высшего учебного заведения, обеспечивающее конкурентоспособность организации на рынке образовательных услуг.

Качество образования, в соответствии с федерального закона «Об образовании» № 273-Ф3 от 31.12.2012 [1] - «это комплексная характеристика образовательной деятельности и подготовки обучающегося...».

Качество высшего образования складывается из нескольких составляющих: качество условий, качество процессов и качество результатов [2]. Все перечисленные составляющие важны и должны рассматриваться только совместно. Вуз оказывает образовательную услугу для потребителей, которыми являются не только обучающиеся, но и также работодатели, преподаватели, общество и государство в целом. Сложность образовательной услуги заключается в следующем: на входе в процесс знания абитуриента являются исходным сырьем, при этом обучающиеся становятся и основными потребителями, реализуемой услуги. На завершающей стадии и конечным продуктом, т.е. квалифицированным специалистом, получившим необходимые знания, умения и навыки.

Современное общество предъявляет к молодым специалистам высокие требования, и чтобы быть конкурентоспособным на рынке труда, качество подготовки должно быть на высоком уровне и удовлетворять интересы всех заинтересованных сторон: освоение общекультурных и профессиональных компетенций, в соответствие с требованиям федеральных государственных стандартов высшего образования, которое приобретаются за счет получения обучающимися теоретических знаний, практических навыков и умений, развития научной мысли и общего уровня воспитания будущих специалистов.

С этой целью образовательной организации, как в России, так и за рубежом активно внедряют систему менеджмента качества в соответствии с требованиями 
международных стандартов семейства ISO 9000, которые позволяют повысить эффективность всех процессов, реализуемых организацией и обеспечить ее устойчивое развитие. Система менеджмента качества (СМК) способствует повышению качества реализуемых организацией процессов. Основным отличием стандарта ISO 9001 версии 2015 года [3] является применяется риск-ориентированного подхода при создании CMK.

Риск это появление какой-либо неопределенности при реализации процесса. При этом возникшая неопределенность может как положительно, так и отрицательно сказаться на качестве процесса. Риск-ориентированное мышление ориентирует организации определять факторы, провоцирующие изменение в качестве реализуемых процессов, используя предупреждающие действия и заранее разработанный инструментарий свести к минимуму негативное влияние, а также оценить и использовать вновь возникшие улучшения. Риск образовательной деятельности возникает под воздействием как внутренних, как и внешних факторов, отрицательно сказывающихся на условия образовательной среды и как следствие результат процесса.

Данным вопрос является актуальным и рассматривался многими авторами [4]. С учетом специфики образовательных заведений риски подразделяют на следующие группы: стратегические - не реализации стратегических целей по качеству; получение отрицательного результата при лицензировании и/или аккредитации; не удовлетворение обучающихся качеством реализуемой услуги и д.р.; операционные несоответствия планирующей документации образовательного учреждения требованиям ФГОС и как следствие выпускники осваивают компетенции не в полном объеме; не эффективная реализация корректирующих и предупреждающих действий в СМК и т.д.

Для гражданина, риск заключается в следующем, полученное высшее образование с целью приобретения конкуренты преимуществ на рынке труда, при негативном результате не позволят: приобрести необходимые теоретические знания, сформировать навыки и умения, раскрыть научный потенциал и в конечном итоге обеспечить достойный уровень жизни и благосостояния.

Для работодателей риски, возникающие в образовательном процессе, приведут к дополнительным затратам на «до обучение» таких специалистов, поскольку выполнение профессиональных обязанностей на высоком уровне, без соответствующей теоретической и практической базы невозможно.

Для общества, описанные выше риски, приведут к дефициту высококвалифицированных кадров во всех сферах деятельности. Риски со стороны государства выражаются в неэффективном использовании бюджетных средств и отсутствием необходимого количества и качества специалистов, способных развивать страну.

К основным рискам вуза следует отнести: недостаточное количество высококвалифицированных преподавателей, недостаточная и/или несоответствующая материально-техническая база и т.д.

Авторы [5] полагают, что целью управления рисками является установление пределов (критериев) допустимого риска и определение алгоритмов сдерживания ситуации в этих пределах. Однако, одной из основных проблем является отсутствие стандартизированных методик по оценке рисков.

При реализации риск-ориентированного подхода проводят качественный и количественный анализ рисков. При управлении рисками, необходимо их идентифицировать и систематизировать, т.е. составить реестр рисков. Реестр рисков составляется по каждому процессу деятельности организации по методике экспертных оценок. В качестве экспертов привлекается квалифицированный персонал, область знаний которого соответствует анализируемому процессу, а степень квалификации, дает возможность идентифицировать опасные события и предложить возможности по 
улучшению, оценке и обработке риска, достаточна для решения проблем. Анализ и оценивание рисков наиболее эффективно представлять в виде матрицы вероятности и последствий, в которых они ранжируются в зависимости от степени воздействия риска на процессы.

На основании результатов качественного и количественного анализа рисков составляется План реагирования на риски, описывающий возможные стратегии для снижения угроз деятельности образовательной организации. Среди рассматриваемых стратегий авторы [5] предлагают следующие: уклонение от риска; передача риска; снижение риска; принятие риска.

ФКОУ ВО «Кузбасский институт ФСИН России» осуществляет подготовку высококвалифицированных кадров и стремится к удовлетворению потребностей всех заинтересованных сторон образовательного процесса. Для повышения качества реализуемой образовательной услуги в вузе разработана и успешно реализуется система менеджмента качества, соответствующая требованиям стандарта ГОСТ Р ИСО 9001-2015.

Разрабатываемая, система оценки и рисков реализуемых процессов образовательного учреждения, позволит значительно повысить уровень качества предоставляемой образовательной услуги.

$$
* * *
$$

1. Федеральный закон от 29.12.2012 N 273-Ф3 (ред. от 29.07.2017) «Об образовании в Российской Федерации».

2. Щеглов П. Е. Качество высшего образования. Риски при подготовке специалистов / П. Е. Щеглов, Н. Ш. Никитина // Университетское управление: практика и анализ. - 2003. - N 1(24). C. $46-59$

3. ГОСТ Р ИСО 9001-2015. Национальный стандарт Российской Федерации. Системы менеджмента качества. Требования.

4. Мухаметзянова Ф.Г., Веселовский А.А. Риски качества высшего образования/ Ф.Г. Мухаметзянова, А.А.Веселовский //Вестник ТИСБИ. - 2016. - Выпуск № 2. - С. 3 - 8.

5. Черненький А.В. Применение риск-ориентированного подхода при построении системы менеджмента качества/ А.В. Черненький // Экономические науки. - 2016. - Выпуск: № 8 (50) Часть 1. - С. $92-96$.

\section{Медведева Е.В, Иванчина О.В. Управление коммуникациями проекта}

Самарский государственный университет путей сообщения (Россия, Самара)

doi:10.18411/spc-8-12-2017-26

idsp: 000001:spc-8-12-2017-26

Управление коммуникациями проекта - это процессы, необходимые для обеспечения быстрой и соответствующей генерации, сбора, распространения, хранения, поиска и окончательный анализ информации о проекте. Руководители проекта большую часть времени проводят во взаимодействии с членами команды и другими заинтересованными лицами проекта - внутренними (на всех организационных уровнях) или внешними.[3]

Процессы управления коммуникациями проекта включают следующее:

○ Определение заинтересованных сторон ○ Планирование метода коммуникаций

○ Распространение информации между участниками проекта

○ Управление ожиданиями заинтересованных сторон ० Отчетность

Планирование коммуникаций состоит в первую очередь в определении информационных потребностей заинтересованных сторон и выявления метода связи, путем ответа на следующие вопросы: кто нуждается в информации, когда она понадобится, как и от кого ее получить для удовлетворения потребностей этих сторон. 